\title{
THE INCIDENCE OF NOSOCOMIAL INFECTIONS IN PATIENTS WITH ISOLATED SEVERE TRAUMATIC BRAIN INJURY
}

\author{
Valencic Lara, ${ }^{1}$ Sotosek Tokmadzic Vlatka, ${ }^{2}$ Kuharic Janja, ${ }^{2}$ Sustic Alan ${ }^{2}$ \\ ${ }^{1}$ Medical Faculty, University of Rijeka, Rijeka, Croatia \\ ${ }^{2}$ Department of Anesthesiology, Reanimatology and Intensive Care, Medical Faculty, \\ University of Rijeka, Rijeka, Croatia
}

Primljen/Received 12. 08. 2015. god.

Abstract: Introduction: Traumatic brain injury is the leading cause of death in children and adults in developed countries. Severe traumatic brain injury is classified with Glasgow Coma Scale score 8 and less. About $50 \%$ of patients with severe traumatic brain injury developes at least one infection as a complication of primary condition during hospitalization in the Intensive Care Unit, resulting with fatal outcome in $28 \%$ of patients. Ventilator - associated pneumonia is the leading infection that affects patients with severe traumatic brain injury, with an incidence between $41 \%$ and $74 \%$. Following are sepsis and urinary tract infections.

The aim: To analyze the number of patients with nosocomial infection and isolated severe traumatic brain injury hospitalized in the Intensive Care Unit of the Clinical Hospital Centre Rijeka, Croatia, from $31^{\text {st }}$ January 2013 to $31^{\text {st }}$ December 2014.

Patients and methods: A two - year retrospective study included 46 patients with isolated severe traumatic brain injury and nosocomial infection hospitalized in the Intensive Care Unit of the Clinical Hospital Centre Rijeka,Croatia, in the period from $31^{\text {st }}$ January 2013 to $31^{\text {st }}$ December 2014. All medical data was collected from the Division of Intensive Care Unit, Clinical Hospital Centre Rijeka, Croatia.

Results: From 67 patients with isolated severe traumatic brain injury, $46(68,65 \%)$ of them developed nosocomial infection. There was statistically significant more male patients than female $(p<0.05)$. The average age of infected patients was 57,8 years. The leading were the infections of the respiratory system. Gram - negative bacteria Proteus mirabilis and Pseudomonas aerugnonsa were the leading pathogens. The average duration of the infection was 5,77 day. Duration of mechanical ventilation accounted for the majority of the patients more than 10 days. The average duration of tre-
Prihvaćen/Accepted 01. 10. 2015. god.

atment for all 46 patients was 10,475 days, and for 16 $(34,78 \%)$ of them, the treatment outcome was lethal.

Conclusion: Nosocomial infections are becoming a major public health problem. The emphasis must be set on the prevention which includes maintaining the hygiene and the antiseptic rules among the medical personnel of the Intensive Care Unit. Already developed infections must be adequately treated so the negative treatment outcomes can be reduced.

Key words: isolated severe traumatic brain injury, Glasgow Coma Scale, Intensive Care Unit, nosocomial infections, gram - negative bacteria.

\section{INTRODUCTION}

Traumatic brain injury (TBI) presents traumatically induced structural damage of brain as a result of external force. It is usually followed by temporary or permanent cognitive brain dysfunction. Some of the early onset clinical signs that can indicate TBI are quantitative loss of consciousness, immediate memory loss before or after the injury, alteration in mental state, neurological sequelae and presence of intracranial lesions (1).

In developed countries, TBI is the leading cause of death in children and adults (2). In European countries, every year is hospitalized about 1,6 milion people with TBI. That formes a brain injury rate of 235/100 000 per year (3). Epidemiological data from Center for disease control and prevention, shows that in the United States TBI makes $30 \%$ of all injury deaths (4). The most vulnerable groups are children aged 0 to 4 , older adolescents between the ages of 15 and 19, and people older than 75 years. Incidence is highest between the ages of 15 and 30, with the greatest risk between the ages of 15 and 24. Men have 1,4 times greater risk compared to 
female (5). The most common cause of TBI are traffic accidents, accounting for $50 \%$. Falls are the second leading cause with $20 \%$ to $30 \%$. Incidence of TBI caused by falls is increasing as the population ages. On that way contusions of brain, that are more frequent in older patients, are becoming the most common biomechanical mechanism of TBI. Violence is the third leading cause, accounting for $7 \%$ to $10 \%$. The incidence of injuries due to firearms rises on the fourth place (6).

Using the most widely applied system for observation and assessment of the level of consciousness called Glasgow Coma Scale (GCS), TBI is divided into the three levels. Scoring the opening of the eyes, verbal and motor response, the total sum from 13 to 15 places the patient into the group with the mild TBI. Total score from 9 do 12 places the patient into the group with moderate TBI. Severe TBI is classified with total score 8 and less (7). Studies indicate that the severity of the injury is proportional to the treatment outcomes; the more difficult injury is related with greater chance of complications and death. Patients with severe TBI are 37 times more likely to die of neurological sequels such as seizures, 12 times more often from sepsis, 4 times more often from pneumonia, and 3 times more often from other respiratory (except pneumonia) and digestive difficulties than healthy population (8). Using the combination of clinical examination and radiological diagnosis, that includes native computed tomography of the brain, it can be achieved prompt diagnosis, and therefore adequate therapy. The aim is to prevent secondary brain injury, primarily hypotension and hypoxia, in order to prevent the patients deterioration and complications like nosocomial infections and potential death (6).

Patients with severe TBI have a high risk for development of nosocomial infections. Nosocomial infections are defined as infections occurred in the hospital environment at least 48 hours from receiving patient for treatment. Approximately $9 \%$ to $37 \%$ of patients admitted to an Intensive Care Unit (ICU), will acquire one or more infections. Risk factors are invasive intensive monitoring, intravenous therapy, mechanical ventilation, and according to some studies, the release of catecholamines after stimulation of the sympathetic nervous system during brain injury that results with induction of systemic immunosuppression $(9,10)$. The incidence of people with severe TBI is only $10 \%$, but is associated with the highest mortality rate which ranges between $30 \%$ and $54 \%$ (11). About $50 \%$ od patients with severe TBI develops at least one infection as a complication of primary condition during hospitalization in ICU, resulting with fatal outcome in $28 \%$ of patients $(9,12,13)$.

Nosocomial, ventilator - associated pneumonia (VAP) is the most common infection that affects patients with severe TBI. The incidence ranges between
$41 \%$ to $74 \%$. The main risk factors for this type of infection are endotracheal intubation and mechanical ventilation. During the first week of hospitalization the risk for developing VAP is $15 \%$, and in the second week rises on $20 \%$ and more. VAP is dived into the two groups. First one is early - onset VAP that occurs in the first 48 to 72 hours from the beginning of intubation and ventilation. It is the result of microaspiration of colonized oropharyngeal secretions and it is caused by pathogens that are sensitive to antimicrobial therapy (13). The second one is late - onset VAP that develops after 72 hours from the beginning of intubation and ventilation. This type of infection is a result of long lasting intubation and ventilation, as well as prophylactic application of broad - spectrum antibiotics. Pathogens are highly virulent and multiresistant. The most common pathogen is gram - negative bacteria Pseudomonas aerugionsa, whose incidence reaches up to $47 \%$ $(14,15)$. Therapy includes de - escalating antibiotic therapy (13).

Patients with severe TBI present one of the most vulnerable group of patients for development of the second most common nosocomial infection called sepsis, whose incidence ranges between $10 \%$ and $41 \%$. The leading cause is bacteremia, while something less frequent causes are fungemia, viremia, and parasitemia $(9,16)$. Early diagnostic is essential for prompt prevention and treatment of this type of infection. Diagnostic criteria for sepsis are documented or suspected infection that is associated with some of the following variables like general, inflammatory, hemodynamic, organ dysfunction and tissue perfusion variables $(17,18)$. Treatment includes adequate intravenous antimicrobial therapy, drainge of abscesses, debridement of necrotic tissue or removal of infected foreign body. The most common is combination of a penicillin/ $\beta$ - lactamases inhibitors or third - generation cephalosporins with an aminoglycosides. It is essential to maintain adequate perfusion with intravenous fluids and inotropic and vasopressor agents (18).

The third most common nosocomial infections are urinary tract infections (UTIs) that are catheter - associated, with an incidence about $15 \%$. Studies show that bacteriuria occurs in patients who require a bladder catheter for longer than 48 hours (19). The leading pathogens are gram - negative bacteria such as Escherichia coli, Enterobacter species, Proteus species, Klebsiella species, non - lactose - fermenting bacteria such as $P s e-$ udomonas aeruginosa, and some other organisms such as staphylococcal species and Enterococcus. Bacteriuria can lead to bacteremia, and subsequently in sepsis in about $5 \%$ of the time. Therapy also includes combination of a penicillin $/ \beta$ - lactamases inhibitors or third generation cephalosporins with an aminoglycosides. 
Prevention of ICU - acquired UTIs is important because UTIs are associated with increased mortality (13).

The aim of this two - year retrospective study was to analyze the number of patients with isolated severe TBI hospitalized in the Intensive Care Unit of the Clinical Hospital Centre Rijeka, Croatia from $1^{\text {st }}$ January 2013 to $31^{\text {st }}$ December 2014, who developed infection during their hospitalization. The aim was also to analyze the type of infection and leading pathogens, as well as the duration of infection and treatment outcomes.

\section{PATIENTS AND METHODS}

This retrospective study was undertaken at Department of Anesthesiology, Reanimatology and Intensive Care, Division for Intensive Care Unit, Clinical Hospital Centre Rijeka, Croatia. It was included 67 patients with isolated severe TBI who where hospitalized in the period from $1^{\text {st }}$ January 2013 to $31^{\text {st }}$ December 2013, and between $1^{\text {st }}$ January 2014 and $31^{\text {st }}$ December 2014. General informations which included the name, surname, gender and age of every patient where considered. From 67 patients with severe TBI, 46 of them developed nosocomial infection. We analyzed GCS score at admission to the ICU, types of nosocomial infections, and the leading pathogens for every hospitalized infected patient with severe TBI during analysis of the study. We analyzed most commonly used antimicrobial drugs in treatment of infected patients, as well as the duration of infection, mechanical ventilation and treatment during the hospitalization in the ICU, so as the treatment outcomes. Privacy rights of all patients where maintained with respect to all ethical and moral standards in accordance with the Declaration of Helsinki.

We collected medical data of all patients from database of Department of Anesthesiology, Reanimatology and Intensive Care, Division for Intensive Care Unit, Clinical Hospital Centre Rijeka, Croatia. All medical records were analyzed using Microsoft Excel. Statistical analysis was performed using STATISTICA 12 (StatSoft, Tulsa, USA). For calculation of statistical significance we used Mann - Whitney non - parametric test for small independent samples, and a chi-squared test for the test of independence of two variables. $\mathrm{P}<0,05$ was considered statistically significant.

\section{RESULTS}

During the period of time from $1^{\text {st }}$ January 2013 to $31^{\text {st }}$ December 2013, at Department of Anesthesiology, Reanimatology and Intensive Care, Division for Intensive Care Unit, Clinical Hospital Centre Rijeka, Croatia, there was 36 hospitalized patients with severe TBI, out of whom $25(69,44 \%)$ developed nosocomial in-

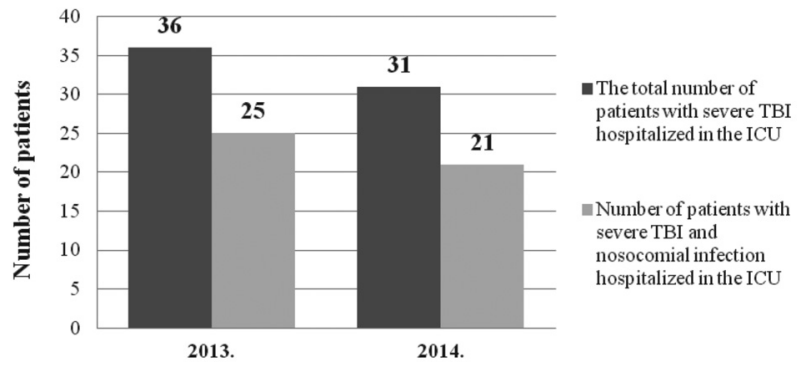

Figure 1. The ratio of the total number of patients with isolated severe TBI compared to the number of patients with severe TBI and nosocomial infection hospitalized in the ICU during the period between $1^{\text {st }}$ January 2013 and $31^{\text {st }}$ December 2014

fection. From $1^{\text {st }}$ January 2014 to $31^{\text {st }}$ December 2014, the total number of patients with severe TBI was 31 , and $21(67,74 \%)$ of them developed nosocomial infection during the hospitalization (Figure 1).

Of the 25 patients with severe TBI and nosocomial infection that were hospitalized in the ICU during the $2013,19(76 \%)$ of them were male gender, and the remaining $6(24 \%)$ were members of the female gender. Out of total number of 21 patient with severe TBI and nosocomial infection during 2014, 16 (76,19\%) of them were male gender, and $5(23,80 \%)$ of them were female gender. Overall, during 2013 and 2014, there was $35(76,08 \%)$ members of male gender, and 11 $(23,91 \%)$ members of female gender with severe TBI and nosocomial infection. There was statistically significant more male gender participant than female (Figure 2).

Of all patients with isolated severe TBI and nosocomial infection in 2013, the largest number of patients was between ages 80 and 89 , and the second were patients between ages 50 and 59 . The average age of patients in 2013 amounted 58,08 years, while the median was 57 years. Analyzing the year 2014, the highest number of patients was also between ages 80 and 89 . Second largest group was between ages 60 and 69. The

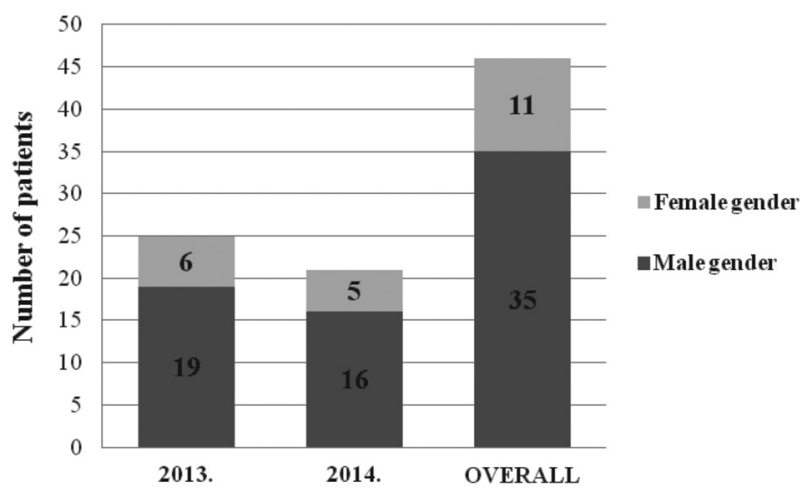

Figure 2. The ratio of patients with isolated severe $T B I$ and nosocomial infection hospitalized in the ICU during 2013 and 2014 according to gender 


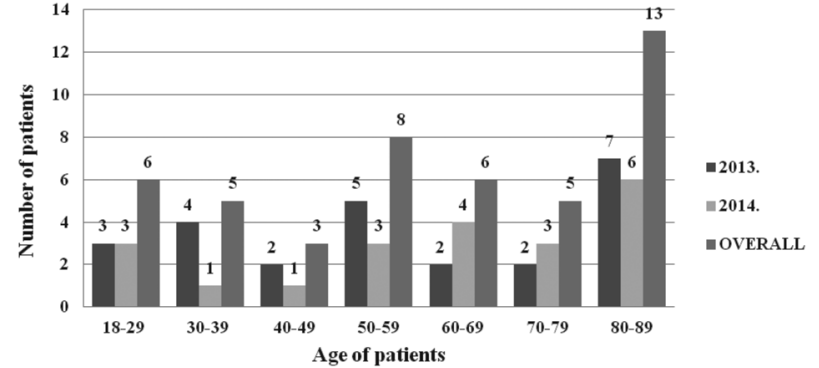

Figure 3. The age distribution of patients with severe $T B I$ and nosocomial infection hospitalized in the ICU during 2013 and 2014

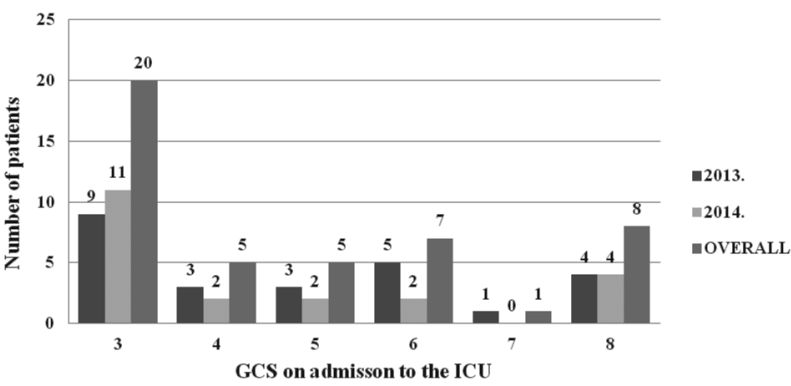

Figure 4. GCS score on the admission to the ICU of the patients with severe TBI and subsequently developed nosocomial infection hospitalized during the year 2013 and 2014

average age for 2014 was 57,52 years, while the median was 67 years. Overall, the largest number of patients was between 80 and 89 years old. The average age was 57,8 years, whil2013e the median was 62 years (Figure 3).

During the admission of patients with severe TBI who subsequently developed nosocomial infection in 2013, GCS for the highest number of patient accounted
Table 1. The leading types of nosocomial infections in patients with severe TBI that were hospitalized in the ICU during year 2013 and 2014

\begin{tabular}{|c|c|c|c|}
\hline Type of the infection & $\begin{array}{c}2013 \\
(\mathrm{n}=25)\end{array}$ & $\begin{array}{c}2014 \\
(\mathrm{n}=21)\end{array}$ & $\begin{array}{c}\text { OVERALL } \\
(\mathrm{n}=46)\end{array}$ \\
\hline $\begin{array}{c}\text { Ventilator - associated } \\
\text { pneumonia (VAP) }\end{array}$ & 6 & 8 & 14 \\
\hline Sepsis & 2 & 1 & 3 \\
\hline $\begin{array}{c}\text { Urinary tract infection } \\
\text { (UTI) }\end{array}$ & 7 & 3 & 10 \\
\hline $\begin{array}{c}\text { Other infections - ordinary } \\
\text { and mucopurulent } \\
\text { bronchitis }\end{array}$ & 10 & 9 & 19 \\
\hline
\end{tabular}

for 3. Also, the same GCS score amounted for the highest number of patients in 2014. Overall, for 2013 and 2014, the highest number of patients were scored GCS 3 (Figure 4).

Respiratory tract infections are proved to be the most common. Leading nosocomial infection for the year 2013 and 2014 was ordinary and mucopurulent bronchitis $(41,30 \%)$. Second most common infection was VAP $(30,43 \%)$. The following are UTIs, which were presented in the $21,73 \%$, and sepsis, which accounted for $6,52 \%$ (Table 1.). In the year 2013, the leading cause of respiratory tract infections were bacteria Proteus mirabilis and Pseudomonas aeruginosa. Sepsis was caused by Candida albicans and Proteus mirabilis, while Escherichia coli was the leading cause of the UTIs (Table 2.). Analyzing the year 2014, Pseudomonas aeruginosa was proved to be the major cause of respiratory tract infections and sepsis. Bacteria Entero-

Table 2. Overview of the leading pathogens considering the type of infection in patients with severe TBI hospitalized in the ICU in the period between $1^{\text {st }}$ January and $31^{\text {st }}$ December 2013.

\begin{tabular}{|c|c|c|c|c|}
\hline Pathogen & $\begin{array}{c}\text { Ventilator - associated } \\
\text { pneumonia (VAP) }\end{array}$ & Sepsis & $\begin{array}{c}\text { Urinary tract infections } \\
\text { (UTI) }\end{array}$ & $\begin{array}{c}\text { Other infections } \\
\text { (ordinary and } \\
\text { mucopurulent bronchitis) }\end{array}$ \\
\hline Escherichia coli & 1 & 0 & 4 & 1 \\
\hline Pseudomonas aeruginosa & 0 & 0 & 0 & 3 \\
\hline Klebsiella pneumoniae & 0 & 0 & 2 & 2 \\
\hline Proteus mirabilis & 2 & 1 & 0 & 1 \\
\hline Proteus vulgaris & 0 & 0 & 0 & 1 \\
\hline Staphylococcus aureus & 1 & 0 & 0 & 0 \\
\hline Enterococcus faecalis & 0 & 0 & 1 & 1 \\
\hline Haemophilus influenzae & 0 & 0 & 0 & 0 \\
\hline Stenotrophomonas maltophila & 1 & 0 & 0 & 0 \\
\hline Serratia marcescens & 0 & 0 & 0 & 10 \\
\hline Candida albicans & 1 & 1 & 0 & \\
\hline OVERALL & 6 & 2 & 7 & \\
\hline
\end{tabular}


Table 3. Overview of the leading pathogens considering the type of infection in patients with sever e TBI hospitalized in the ICU in the period between $1^{\text {st }}$ January and $31^{\text {st }}$ December 2014.

\begin{tabular}{|c|c|c|c|c|}
\hline Pathogen & $\begin{array}{c}\text { Ventilator - associated } \\
\text { pneumonia (VAP) }\end{array}$ & Sepsis & $\begin{array}{c}\text { Urinary tract infections } \\
\text { (UTI) }\end{array}$ & $\begin{array}{c}\text { Other infections } \\
\text { (ordinary and } \\
\text { mucopurulent } \\
\text { bronchitis) }\end{array}$ \\
\hline Escherichia coli & 0 & 0 & 1 & 0 \\
\hline Pseudomonas aeruginosa & 4 & 1 & 0 & 4 \\
\hline Klebsiella pneumoniae & 0 & 0 & 0 & 0 \\
\hline Proteus mirabilis & 0 & 0 & 0 & 0 \\
\hline Proteus vulgaris & 0 & 0 & 0 & 0 \\
\hline Staphylococcus aures & 0 & 0 & 2 & 0 \\
\hline Enterococcus faecalis & 1 & 0 & 0 & 0 \\
\hline Haemophilus influenzae & 0 & 0 & 0 & 2 \\
\hline Stenotrophomonas maltophila & 0 & 0 & 0 & 2 \\
\hline Serratia marcescens & 2 & 0 & 0 & 9 \\
\hline Candida albicans & 1 & 0 & 3 & 0 \\
\hline OVERALL & 8 & 1 & & 0 \\
\hline
\end{tabular}

coccus faecalis is determined as leading cause of UTIs (Table 3.).

The most commonly used antimicrobial medications to treat infected patients in the ICU during 2013 and 2014, were the beta - lactam antibiotics involving meropenem, cloxacillin, and a combination of piperacillin and tazobactam. In the second place where cephalosporins such as cefazolin, cefepime, ceftriaxone. Less frequently used group of antimicrobial medications were non - beta lactam antibiotics including teicoplanin and vankomycin. Other used medications where aminoglycosides, quinolones, medications against anaerobic bacteria and fungal infection (Figure 5).

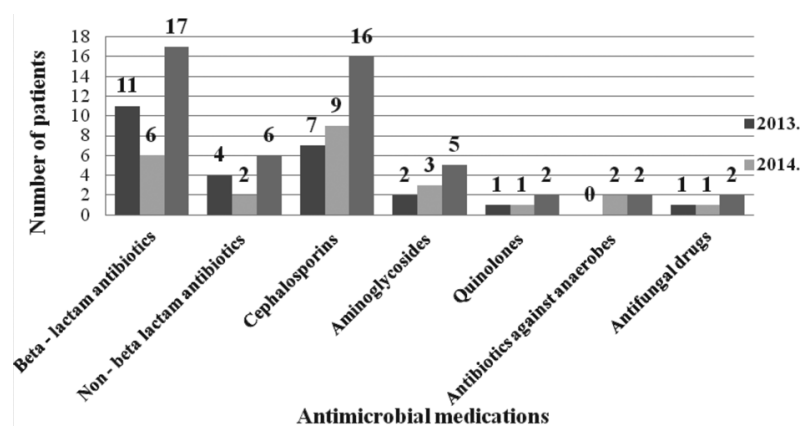

Figure 5. Antimicrobial medications used in the treatment of patients with nosocomial infection and isolated severe TBI hospitalized in the ICU during the year 2013 and 2014

Duration of infection in days, overall in the 2013 and 2014, was for the majority of patients longer than 7 days with an average of 5,77 days (Figure 6).

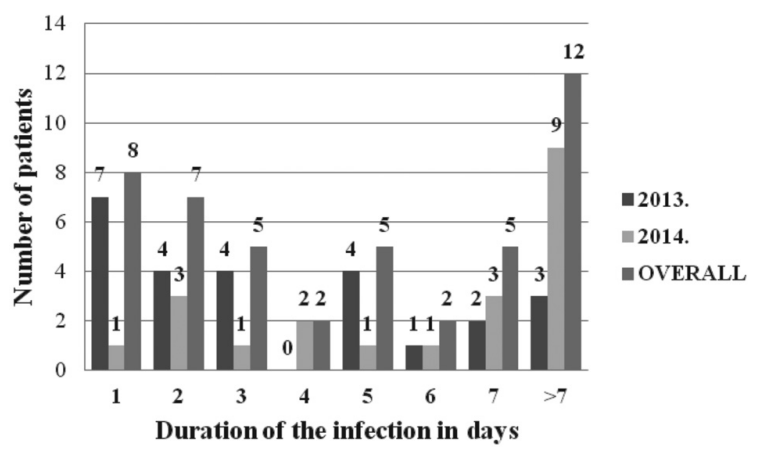

Figure 6. Duration of the infections in days in patients with isolated severe TBI and nosocomial infection hospitalized in the ICU during 2013 and 2014

Overall in 2013 and 2014, duration of mechanical ventilation for patients with infection was for most of them more than 10 days (Figure 7).

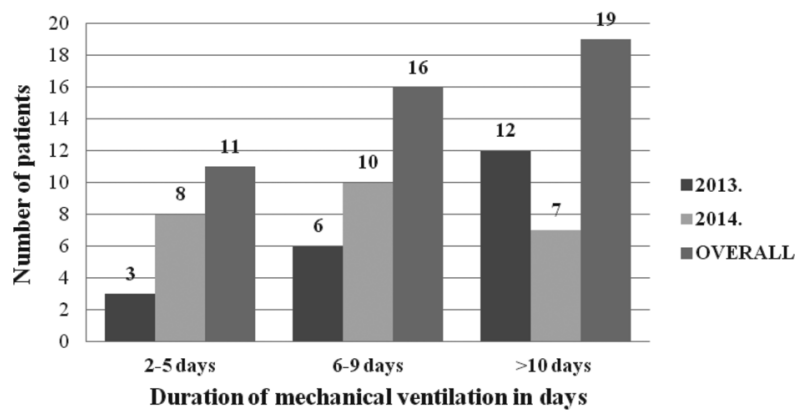

Figure 7. Duration of mechanical ventilation in days in patients with isolated severe TBI and nosocomial infection hospitalized in the ICU during 2013 and 2014 
The average duration of treatment of patients in the ICU, was in 2013 and 2014 overall 10,475 days (Figure 8).

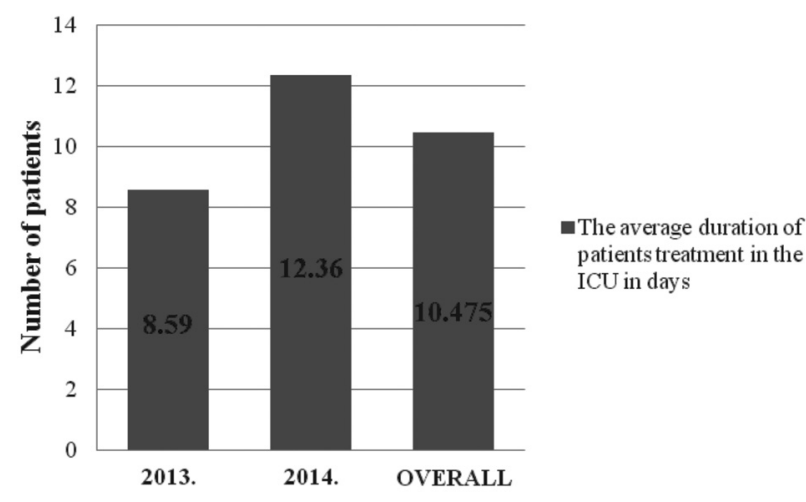

Figure 8. The average duration of treatment of patients with nosocomial infetion and isolated severe TBI hospitalized in the ICU during 2013 and 2014

From 46 patients with isolated severe TBI and nosocomial infection, $29(63,04 \%)$ was dismissed to the Department of Neurosurgery. For $16(34,78 \%)$ patients treatment outcome was lethal, and $1(2,17 \%)$ patient was dismissed to the Department of Pulmolonary Medicine (Figure 9).

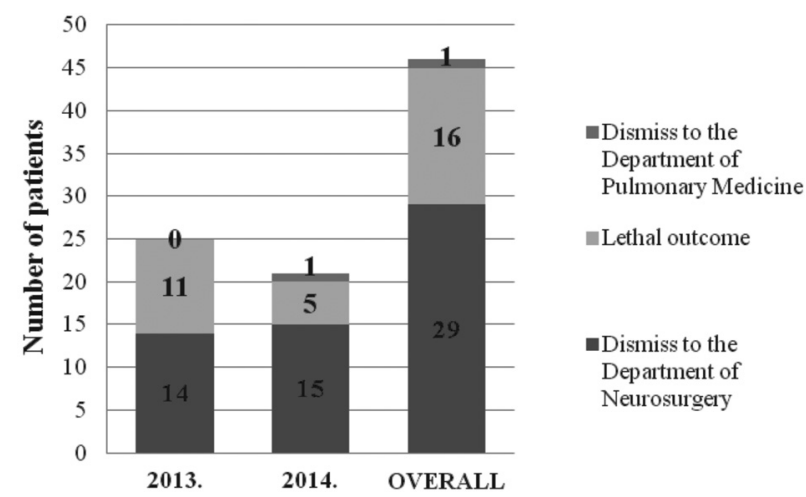

Figure 9. Treatment outcomes in patients with severe TBI and nosocomial infection hospitalized in the ICU during 2013 and 2014

\section{DISCUSSION}

Based on the results of analysis that was undertaken at the Department of Anesthesiology, Reanimatology and Intensive Care, Division of Intensive Care Unit, Clinical Hospital Centre Rijeka in a period of time between $1^{\text {st }}$ January 2013 and $31^{\text {st }}$ December 2013, the incidence of nosocomial infections in patients with severe TBI was $69,44 \%$. During the period between $1^{\text {st }}$ January 2014 and $31^{\text {st }}$ December 2014, incidence was $67,74 \%$. These results show a higher incidence of nosocomial infections in patients with severe TBI compared to global studies, where the percentage of infections in patients with severe TBI is about $50 \%(9,12$,
13). The results can be explained by the presence of multiresistant pathogens that are found in the ICU, and are transmitted primarily through medical personnel, despite their efforts to maintain hygiene and antiseptic rules. Medical personnel must be familiar with the standards of control of hospital infections.

According to gender of infected patients with severe TBI, during 2013 and 2014, overall was hospitalized $76,08 \%$ members of male gender, and the remaining $23,09 \%$ were female members. There was statistically significantly more male gender members than female $(\mathrm{p}<0.05)$. Results are confirmed by the fact that members of male gender have 1,4 times higher risk for the development of severe TBI, and consequently of nosocomial infections (5).

Analyzing the age distribution of patients with nosocomial infection and severe TBI, it was observed that the incidence of nosocomial infections was highest at the oldest patients between ages 80 and 89 . On the second place was working population aged between 50 and 59 years old, and in third young people aged between 18 and 29 years old. The average age of all infected patients with severe TBI was 57,8 years, and median was 62 years. Comparing the results with the global literature, we confirm that the most vulnerable group of patients is the one aged 75 and more, as well as the population aged between 15 and 30 years old (5). An average age of 57,8 years is associated with the fact that it is the active working population, increasing on that way the risk of accidents and consequent injury.

Out of 46 patients with nosocomial infection and severe TBI, $20(43,47 \%)$ of them had on the admission to the ICU, GCS score 3. Severe TBI is defined as GCS score 8 and less. The lower GCS score is proportional with higher risk for development of complications, including nosocomial infections, thus increasing the risk of lethal outcome (8).

From all 46 patients with nosocomial infection and severe TBI, $14(30,43 \%)$ had been diagnosed with VAP, $3(6,52 \%)$ of them with sepsis, and UTI had 10 $(21,73 \%)$ patients. The leading infection was ordinary and mucopurulent bronchitis which occurred in a total of $19(41,30 \%)$ patients. As is confirmed by other studies, including our own, the most common are respiratory tract infections which predispose endotracheal intubation and mechanical ventilation. Ordinary and mucopurulent bronchitis consequently leads to VAP. Following infections are sepsis and UTI, and that corresponds to the incidence recorded in the world literature $(9,12$, 13, 20, 21). The leading pathogens were Proteus mirabilis in a year 2013, and Pseudomonas aeruginosa for the year 2014. These bacteria belong to the group of gram negative multiresistance pathogens that are the leading etiological causes of nosocomial infections $(12,13)$. 
Most commonly used antimicrobial drugs were beta - lactamic group of antibiotics, and cephalosporins, which is in accordance with the world literatue (13).

The average duration of infection, overall in 2013 and 2014, was 5,77 days. Overall, duration of mechanical ventilation was more than 10 days, and average length of patients treatment in days was 10,475 days. It is essential to start with adequate treatment and to set early tracheostomy so the hospitalization can be shorter, and consequently the risk of negative treatment outcomes can be reduced (12).

Treatment outcome was for $29(63,04 \%)$ of 46 patients dismiss to the Department of Neurosurgery, for $16(34,78 \%)$ patients outcome was lethal, and 1 $(2,17 \%)$ patient was dismissed to the Department of Pulmonary Medicine. According to global literature, mortality from severe TBI is between $31 \%$ and $54 \%$, and if it is complicated with nosocomial infection it rises to $70 \%(11,13)$. Comparing this records with results of our analysis, we conclude that lethal outcome in patients with nosocomial infection and severe TBI is at the lower limit, which indicates on early and adequate therapy and positive treatment outcomes.

\section{CONCLUSION}

Based on our retrospective study, we can conclude that the incidence of nosocomial infections in patients with severe TBI can be equated with an incidence that is recorded in the global literature. The leading cause of this posttraumatic complications is presence of mul- tiresistant pathogens in the ICU. Severe TBI complicated by nosocomial infections leads to prolonged hospitalization, thus raising the cost of treatment. On that way, nosocomial infections in patients with severe TBI are becoming one of the major global health problems. The emphasis must be set on prevention of nosocomial infections, where the key role has medical personnel of the ICU. Maintenance of hygiene and antiseptic rules is one way how the nosocomial infections can be prevented among this difficult group of patients. Medical personnel must be familiar with the standards of control of hospital infections. Also, proper care of the patient such as placing the patient in the appropriate position, and use of a mobile bed, may help prevent the development of nosocomial infections. Already developed nosocomial infection should be recognized and adequately treated in order to improve patients treatment course, and to reduce the number of potential negative treatment outcomes.

DECLARATION OF INTEREST. None.

ACKNOWLEDGMENTS. This work was supported by the grand of Univeristy of Rijeka, Rijeka, Croatia (grant no. 13.06.1.1.12)
ABBREVIATIONS
GCS - Glasgow Coma Scale
ICU - Intensive Care Unit
TBI - Traumatic Brain Injury
UTI - Urinary Tract Infection
VAP - Ventilator - Associated Pneumonia

\title{
Sažetak
}

\section{UČESTALOST BOLNIČKIH INFEKCIJA KOD PACIJENATA SA IZOLOVANOM TEŠKOM POVREDOM MOZGA}

\author{
Valencic Lara, ${ }^{1}$ Sotosek Tokmadzic Vlatka, ${ }^{2}$ Kuharic Janja, ${ }^{2}$ Sustic Alan ${ }^{2}$ \\ ${ }^{1}$ Medicinski fakultet, Univerzitet u Rijeci, Rijeka, Hrvatska \\ ${ }^{2}$ Jedinica intenzivnog lečenja Klinike za anesteziologiju, reanimatologiju i intenzivno lečenje, \\ Medicinski fakultet, Univerzitet u Rijeci, Rijeka, Hrvatska
}

Uvod: Traumatska povreda mozga je vodeći uzrok smrti kod dece i odraslih u razvijenim zemljama. Teška traumatska povreda mozga se Glasgow koma skalom klasifikuje skorom 8 i manje. Oko 50\% pacijenata sa teškom traumatskom povredom mozga razvije barem jednu infekciju kao komplikaciju primarnog stanja tokom hospitalizacije u Jedinici intenzivnog lečenja, što u $28 \%$ slučajeva rezultira fatalnim ishodom. Vodeća infekcija kod pacijenata sa teškom traumatskom povredom mozga je pneumonija vezana za asistiranu ventilaciju, sa incidencom $41 \%$ i $74 \%$. Slede sepsa i infekcija urinarnog trakta.

Cilj: Analizirati broj pacijenata sa bolničkom infekcijom i izolovanom teškom traumatskom povredom mozga, hospitalizovanih u Jedinici intenzivnog lečenja Klinike za anesteziologiju, reanimatologiju i intenzivno lečenje Kliničko bolničkog centra Rijeka, Hrvatska, od 31. januara 2013. do 31. decembra 2014. godine.

Pacijenti i metode: Dvogodišnja retrospektivna studija je uključila 46 pacijenata sa izolovanom teškom traumatskom povredom mozga i bolničkom infekcijom, hospitalizovanih u Jedinici intenzivnog lečenja Klinike za anesteziologiju, reanimatologiju i intenzivno lečenje Kliničko bolničkog centra Rijeka, Hrvatska, od 31. januara 2013. do 31. decembra 2014. godine. Svi medicinski podaci prikupljeni su iz Jedinice intenzivnog lečenja Kliničko bolničkog centra Rijeka, Hrvatska. 
Rezultati: Od 67 pacijenata sa izolovanom teškom traumatskom povredom mozga, $46(68,65 \%)$ od njih dobilo je bolničku infekciju. Broj muških pacijenata je statistički značajno veči od broja ženskih pacijenata $(\mathrm{p}<$ $0.05)$. Prosečne godine starosti pacijenata su 57,8 godina. Vodeće su su bile infekcije respiratornog trakta. Gram - negativne bakterije, Proteus mirabilis i Pseudomonas aerugnonsa, su se pokazale kao najčešći patogeni uzročnici. Prosečno trajanje infekcije bilo je 5,77 dana. Trajanje mehaničke ventilacije je kod većine pacijenata trajalo više od 10 dana. Prosečno trajanje lečenja

\section{REFERENCES}

1. Silver JM, McAllister TW, Yudofsky SC. Textbook of Traumatic Brain Injury. 2nd ed. Arlington: American Psychiatric Publishing, 2011.

2. Dombovy ML. Traumatic Brain Injury. Continuum (Minneap Minn). 2011; 17(3): 584-605.

3. Berg J, Tagliaferri F, Servadei F. Cost of trauma in Europe. Eur J Neurol. 2005; 12 (suppl 1): 85-90.

4. Faul M, Xu L, Wald MM, Coronado VG. Traumatic brain injury in the United States: emergency department visits, hospitalizations, and deaths. Atlanta (GA): Centers for Disease Control and Prevention, National Center for Injury Prevention and Control, 2010.

5. Kraus JF, Black MA, Hessol N et al. The incidence of acute brain injury and serious impairment in a defined population. Am J Epidemiol. 1984; 119(2): 186-201.

6. Maas AI, Stocchetti N, Bullock R. Moderate and severe traumatic brain injury in adults. Lancet Neurol. 2008; 7(8): 728-41.

7. Teasdale G, Murray LP, Parker L, Jennett B. Adding up the Glasgow Coma Score. Acta Neurochir Suppl (Wien). 1979; 28(1): 13-6.

8. Harrison - Felix C, Whiteneck G, Devivo MJ, Hammond FM, Jha A. Causes of death following 1 year postinjury among individuals with traumatic brain injury. J Head Trauma Rehabil. 2006; 21(1): 22-33.

9. Scott BNV, Roberts DJ, Robertson HL et al. Incidence, prevalence, and occurrence rate of infection among adults hospitalized after traumatic brain injury: study protocol for a systematic review and meta - analysis. Syst Rev. 2013; 2:68.

10. Dziedzic T, Slowik A, Szczudlik A. Nosocomial infections and immunity: lesson from brain - injured patients. Crit Care. $2004 ; 8(4)$ : 266-70.

11. Zygun DA, Zuege D, Boiteau PJ et al. Ventilator - associated pneumonia in severe traumatic brain injury. Neurocrit Care. 2006; 5(2): 108-14.

\section{Correspondence to/Autor za korespondenciju}

Vlatka Sotošek Tokmadžić

Department of Anesthesiology,

Reanimatology and Intensive Care, Medical Faculty, University of Rijeka,

Tome Strižića 3, 51000 Rijeka, Croatia

Telephone number: +38551407400

Fax number: +38551218400

E-mail: vlatkast@medri.uniri.hr kod svih 46 pacijenata bilo je 10.475 dana, kod 16 $(34,78 \%)$ od njih, ishod lečenja bio je letalan.

Zaključak: Bolničke infekcije postaju veliki ozbiljan problem javnog zdravlja. Akcenat mora biti na prevenciji koja uključuje održavanje higijene i poštovanje pravila antisepse među medicinskim osobljem Jedinice intenzivnog lečenja. Već razvijene infekcije moraju biti adekvatno lečene kako bi se redukovali negativni ishodi lečenja.

Ključne reči: izolovana traumatska povreda mozga, Glasgow koma skala, Jedinica intenzivnog lečenja, bolničke infekcije, gram - negativne bakterije.

12. Brain Trauma Foundation, American Association of Neurological Surgeons (AANS), Congress of Neurological Surgeons (CNS), AANS/CNS Joint Section on Neurotrauma and Critical Care. Guidelines for the management of severe traumatic brain injury. 3rd ed. Journal of Neurotrauma 2007; 24(1).

13. Hallman MR, Treggiari MM, Deem S. Critical Care Medicine. In: Barash PG, eds. Clinical Anesthesia. $7^{\text {th }}$ ed. Philadelphia: Lippincott Williams\&Wilkins, 2013: 1580-610.

14. Bauer TT, Ferrer R, Angrill J, Schultze - Werninghaus G, Torres A. Ventilator - associated pneumonia: incidence, risk factors, and microbiology. Semin Respir Infect. 2000; 15(4): 272-9.

15. Giantsou E, Liratzopoulos N, Efraimidou E et al. Both early - onset and late - onset ventilator - associated pneumonia are caused mainly by potentially multiresistant bacteria. Intensive Care Med. 2005; 31(11): 1488-94.

16. Cardozo LCM, Da Silva RR. Sepsis in intensive care unit patients with traumatic brain injury: factors associated with higher mortality. Rev Bras Ter Intensiva. 2014; 26(2): 148-54.

17. Hoover L, Bochicchio GV, Napolitano LM et al. Systemic inflammatory response syndrome and nosocomial infection in trauma. J Trauma. 2006; 61(2): 310-16.

18. Critical Care. In: Butterworth JF, Mackey DC, Wasnick JD. Morgan \& Mikhail's Clinical Anesthesiology. $5^{\text {th }}$ ed. New York: The McGraw - Hill Education, LLC, 2013: 1312-19.

19. Leone M, Albanese J, Garnier F et al. Risk factors of nosocomial catheter - associated urinary tract infection in a polyvalent intensive care unit. Intensive Care Med. 2003; 29(6): 929-32.

20. Kourbeti IS, Vakis AF, Papadakis JA et al. Infections in traumatic brain injury patients. Clin Microbiol Infect. 2012; 18(4): 359-64.

21. Mascia L, Sakr Y, Pasero D, Payen D, Reinhart K, Vincent JL. Extracranial complications in patients with acute brain injury: a post - hoc analysis of the SOAP. Intensive Care Med. 2008; 34(4): 720-7. 